The INL is a

U.S. Department of Energy

National Laboratory

operated by

Battelle Energy Alliance

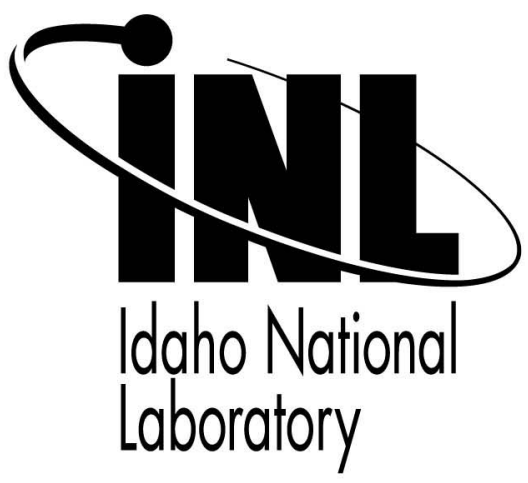

\title{
Selective Trapping of Volatile Fission Products With an Off-Gas Treatment System
}

\section{Fifteenth Symposium on Separation Science and Technology for Energy Applications}

B. R. Westphal

J. J. Park

J. M. Shin

G. I. Park

K. J. Bateman

D. L. Wahlquist

\section{July 2008}

This is a preprint of a paper intended for publication in a journal or proceedings. Since changes may be made before publication, this preprint should not be cited or reproduced without permission of the author. This document was prepared as an account of work sponsored by an agency of the United States Government. Neither the United States Government nor any agency thereof, or any of their employees, makes any warranty, expressed or implied, or assumes any legal liability or responsibility for any third party's use, or the results of such use, of any information, apparatus, product or process disclosed in this report, or represents that its use by such third party would not infringe privately owned rights. The views expressed in this paper are not necessarily those of the United States Government or the sponsoring agency. 


\title{
Selective Trapping of Volatile Fission Products with an Off-Gas Treatment System
}

\author{
B. R. Westphal, ${ }^{1}$ J. J. Park, ${ }^{2}$ J. M. Shin, ${ }^{2}$ G. I. Park, ${ }^{2}$ \\ K. J. Bateman, ${ }^{1}$ and D. L. Wahlquist ${ }^{1}$ \\ 'Idaho National Laboratory, Idaho Falls, ID, USA \\ ${ }^{2}$ Korea Atomic Energy Research Institute, \\ Yuseong, Daejeon
}

\begin{abstract}
An off-gas treatment system is being developed for the collection of volatile fission products during a head-end processing step. The head-end processing step employs high temperatures to oxidize $\mathrm{UO}_{2}$ to $\mathrm{U}_{3} \mathrm{O}_{8}$ resulting in the separation of fuel from cladding and the removal of volatile fission products. Three volatile fission products have been targeted for trapping on distinct zones of the off-gas system and within those zones, on individual filters. A description of the filter media and a basis for its selection will be given along with the collection mechanisms and design considerations. Results from testing with the off-gas treatment system will also be presented.
\end{abstract}

Keywords: Fission products; off-gas collection; volatile

\section{INTRODUCTION}

A head-end processing step is being developed for the treatment of spent oxide fuel by the Idaho National Laboraotory (INL) in collaboration with the Korea Atomic Energy Research Institute (KAERI) through an International Nuclear Energy Research Initiative. The head-end step, termed OREOX or DEOX $(1,2)$, prepares the fuel for downstream processes by decladding the spent fuel, sizing the fuel particles, and removing volatile fission products. For the pyroprocessing of spent oxide fuel, the downstream processes include an electrolytic oxide reduction step followed by electrorefining $(3,4)$. During electrolytic reduction, uranium 
oxide is reduced to metallic uranium via a lithium molten salt so that the final recovery of uranium can be performed by electrorefining. All of these processes are performed in an inert-shielded hot cell requiring remote-handled operations.

The head-end step is based on previous investigations $(5,6)$ and employs high temperatures to promote the oxidation of $\mathrm{UO}_{2}$ to $\mathrm{U}_{3} \mathrm{O}_{8}$ via reaction with gaseous oxygen. During oxidation, the spent fuel experiences a $30 \%$ increase in lattice structure volume resulting in the separation of fuel from cladding with a reduced particle size. A potential added benefit of the head-end step is the removal of fission products, either by direct release from the broken fuel structure or by oxidation and volatilization by the high temperature process (2-7).

Recently, the KAERI and the INL have collaborated on the design of an off-gas treatment system capable of selectively trapping volatile fission products. The volatile elements targeted for trapping are iodine, technetium, and cesium based on their long-term effects in a repository setting (8). Each element is intended to be collected in distinct zones of the off-gas system and within that zone, on individual filters. The filter medium for each zone has been specifically selected to trap the element of interest. A description of the filter media and a basis for its selection will be given along with the collection mechanisms and design considerations. Results from recent testing with irradiated fuels will also be presented.

\section{EXPERIMENTAL}

A brief description of the off-gas treatment system, the filter media, the experimental conditions, and the analytical procedures follows.

\section{Off-Gas Treatment System}

The off-gas treatment system (OTS) is incorporated into a vertical, splittube furnace with four separate heating zones; the lowest or Zone 4 for oxidation of the fuel and three other zones for collection of volatile off-gases (Fig. 1). The three upper filter zones are designed to collect specific volatile species following oxidation based on the operating parameters and filter media for each zone. Zone 1 is capable of $500^{\circ} \mathrm{C}$, while Zones 2 and 3 can be operated to $1000^{\circ} \mathrm{C}$. The design temperature for Zone 4 is $1400^{\circ} \mathrm{C}$ although operation has been at lower temperatures. The experimental set-up includes a gas delivery system to control the flow of air or oxygen and a vacuum pump capable of reducing the operating pressures to less than $100 \mathrm{mT}$ Torr. The furnace and gas delivery system are 


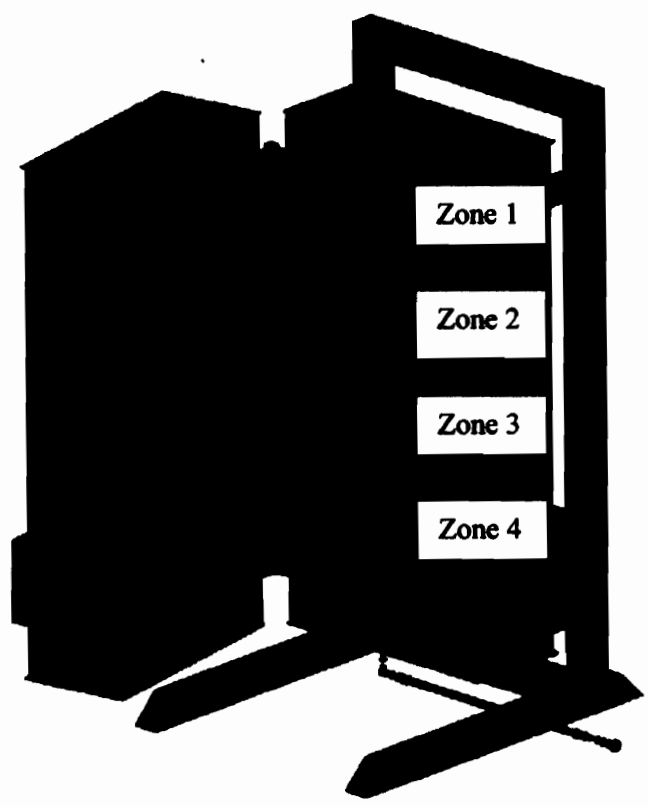

Figure 1. Off-gas treatment system with furnace.

specifically designed for remote disassembly and maintenance considering their location inside the hot cell.

The primary connections for the OTS assembly are made outside the furnace so that the filters can be assembled and leak-checked outside the hot cell environment. Loading of the fuel into a crucible is performed in the hot cell and final connections are made to seal the assembly from the internals of the furnace. A unique nickel gasket has been designed for Zone 4 due to its higher operating temperature and atmospheric conditions. Gasket materials for Zones 1-3 include Viton ${ }^{\mathrm{B}}$ seals and c-shaped Inconel ${ }^{\mathbb{E}} 600$ depending on the zone temperature. The structural components of the OTS assembly are primarily 304 stainless steel except in Zone 4 where Inconel ${ }^{10} 600$ is utilized due to the higher temperatures.

\section{Filter Media}

The filter media are enclosed in stainless steel cartridges for the three trapping zones as shown in Fig. 2. Two kinds of cartridges are used for 
B. R. Westphal et al.

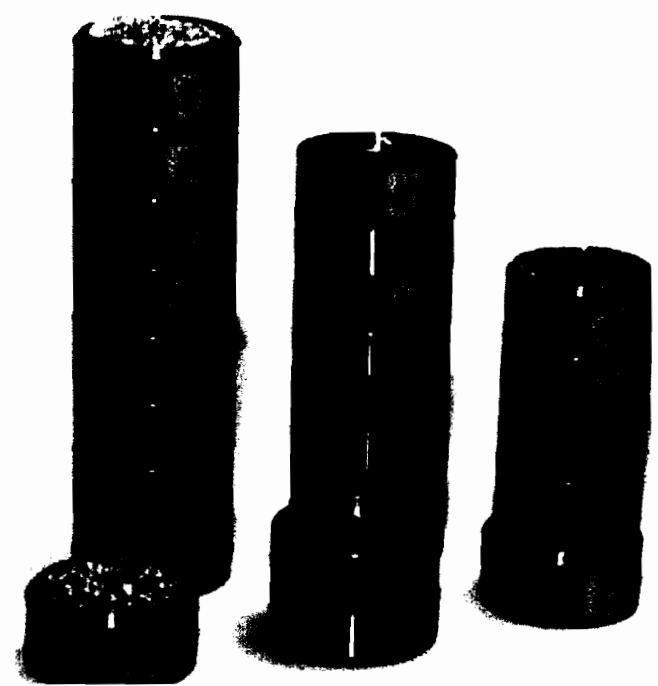

Figure 2. Filter media includes zeolite (center) and aluminosilicate (left, right) based materials.

the filter media; a mesh-type and a disk-type. The mesh-type cartridges, with approximate dimensions of $2.5 \mathrm{~cm}$ diameter by $1.2 \mathrm{~cm}$ length, contain granular zeolite media while the disk-type $(2.5 \mathrm{~cm}$ diameter by $0.5 \mathrm{~cm}$ length) encase a high surface area aluminosilicate disk.

For Zone 1, the media inside the mesh-type cartridges consists of silver ion-exchanged zeolite $(\mathrm{AgX})$ adsorbent (9). Silver-based adsorbents have been demonstrated to form stable iodine compounds (AgI) upon reaction with gaseous iodine species (10). Approximately $2.5 \mathrm{~g}$ (dry) of beads or granular $\mathrm{AgX}$ zeolite is loaded per threaded cartridge and contained by mesh screens in the five filters of Zone 1.

Technetium and cesium are the targeted volatile fission products to be collected in Zones 2 and 3, respectively. For Zone 2, there are nine disk-type filters and for Zone 3 there are five (Fig. 2). The aluminosilicate disks are cemented into the stainless steel cartridges by an alumina paste. Fly-ash was chosen as the substrate material for filters in Zones 2 and 3 based on its availability from the coal industry and waste utilization potential $(11,12)$. The silicon to aluminum ratio of fly-ash is approximately $2: 1$, matching that of the stable cesium aluminosilicate phase of pollucite $\left(\mathrm{CsAlSi}_{2} \mathrm{O}_{6}\right)$. Pollucite has been recognized as a superior immobilization host for radioactive cesium $(13,14)$. For Zone 2, calcia has been 


\section{Selective Trapping of Volatile Fission Products}

Table 1. Design criteria for the filter media in Zones 1,2 , and 3

\begin{tabular}{lcccccr}
\hline Zone & $\begin{array}{c}\text { Filter } \\
\text { media }\end{array}$ & $\begin{array}{c}\text { Trapping } \\
\text { element }\end{array}$ & $\begin{array}{c}\text { Operating } \\
\text { temp. (C) }\end{array}$ & $\begin{array}{c}\text { Superficial } \\
\text { gas velocity } \\
(\mathrm{cm} / \mathrm{sec})\end{array}$ & $\begin{array}{c}\text { Bed } \\
\text { height } \\
(\mathrm{cm})\end{array}$ & $\begin{array}{c}\text { Theoretical } \\
\text { capacity } \\
(\mathrm{mg} / \mathrm{g} \text { media) }\end{array}$ \\
\hline 1 & AgX Zeolite & I & 150 & $<20$ & 5 & 105 \\
2 & CaO/Fly-ash & Tc & 600 & $<20$ & 8 & $1750 / 349$ \\
3 & Fly-ash & Cs & 1000 & $<20$ & 4 & 675 \\
\hline
\end{tabular}

added to the fly-ash matrix to react with technetium according to the following reactions:

$$
\begin{gathered}
\mathrm{CaO}(\mathrm{s})+\mathrm{Tc}_{2} \mathrm{O}_{7}(\mathrm{~g})=\mathrm{Ca}\left(\mathrm{TcO}_{4}\right)_{2}(\mathrm{~s}) \\
5 \mathrm{CaO}(\mathrm{s})+\mathrm{Tc}_{2} \mathrm{O}_{7}(\mathrm{~g})=\mathrm{Ca}_{5} \mathrm{Tc}_{2} \mathrm{O}_{12}(\mathrm{~s})
\end{gathered}
$$

The basis for reacting an alkaline earth compound, such as calcia, with a volatile noble metal species has been reported previously (15). The aluminosilicate disks for Zones 2 and 3 typically weigh around $1 \mathrm{~g}$ per disk.

The intended mechanism for trapping in all three collection zones is adsorption of the volatile species onto the filter media. Whether the initial adsorption mechanism is a physical or chemical attraction is not relevant because thermodynamically-stable species are formed on the filter media as determined by XRD, TGA, and SEM-EDX analyses with surrogate materials in testing at KAERI $(9,16,17)$.

The design criteria shown in Table 1 for the filter media have been established through the aforementioned testing at the KAERI. Tests were performed under varying conditions with volatile species to arrive at the optimum temperatures, gas velocities, and bed heights given in Table 1. The number of cartridges required for each zone is based on these criteria. Also included in Table 1 are reference data for theoretical filter capacities. These data represent saturated filters under optimum conditions based on the stoichiometry of the compound formed with the trapping element. Two values are shown for the $\mathrm{CaO} /$ fly-ash filters based on equations (1) and (2), respectively.

\section{Test Conditions}

Off-gas testing with irradiated oxide fuel is performed in the Hot Fuel Examination Facility (HFEF) hot cell located at the INL. The spent oxide fuel used for testing originated from the Belgium Reactor-3 (BR-3), a pressurized water reactor located in Mol, Belgium. The BR-3 fuel has a typical burnup of $\sim 37 \mathrm{GWd} / \mathrm{t}$ with a 27 year decay time and 
zircaloy-4 type cladding. Segments of approximately $2.5 \mathrm{~cm}$ in length are sectioned from a BR-3 spent oxide fuel rod and loaded into a stand that keeps the segments vertical while processing. The stand is then placed into a crucible and loaded into the outer containment vessel of Zone 4 . The nominal batch size is $100 \mathrm{~g}$ of fuel and cladding per test.

Oxidation of the spent fuel commences with either oxygen or air supplied as the furnace heats at approximately $10^{\circ} \mathrm{C} / \mathrm{min}$ to $500^{\circ} \mathrm{C}$. At $500^{\circ} \mathrm{C}$, the temperature in Zone 4 is held for $3 \mathrm{hrs}$ under the flow $(0.5 \mathrm{~L} / \mathrm{min})$ of oxidative gas. Following the oxidation cycle, the system is evacuated $\left(<1\right.$ Torr) and heating continues at approximately $10^{\circ} \mathrm{C} / \mathrm{min}$ to $1200^{\circ} \mathrm{C}$. Zones 1,2 , and 3 are maintained at constant temperature throughout the entire sequence given. Zone 1 is at $150^{\circ} \mathrm{C}$, Zone 2 is at $600^{\circ} \mathrm{C}$, and Zone 3 is at $800-1000^{\circ} \mathrm{C}$.

Three tests with irradiated BR-3 fuel have been performed in the HFEF for the collection of volatile off-gases in the OTS. Following the first test, it was recognized that incomplete oxidation of the fuel had occurred by the lack of fuel fines and the difficulty in extracting fuel from the cladding. Modifications to the crucible were implemented to assure passage of oxygen over the clad fuel for follow-on tests. Sampling and chemical analysis of the crucible following Test 2 revealed that a significant amount of volatile fission products were being retained by the crucible matrix $\left(\mathrm{Al}_{2} \mathrm{O}_{3}-\mathrm{SiO}_{2}\right)$. For Test 3 , an Inconel ${ }^{\mathrm{B}}$ crucible was installed to alleviate reaction of the volatiles with the crucible. In addition, the operating temperature of Zone 3 was increased to $1000^{\circ} \mathrm{C}$ from $800^{\circ} \mathrm{C}$ for Test 3 based on input from KAERI on improved collection efficiency.

\section{Analytical Procedures}

Following each test, samples are taken of the oxidized fuel and individual filters so that chemical analyses can be performed in the Analytical Laboratory. The fuel fines following a test are dissolved and analyzed for comparison with pre-test fuel to determine the extent of fission product removal (7). For the filters,each filter isweighed, dissolved/leached, and the resultant solutions are analyzed by inductively coupled plasma mass spectrometry (ICP-MS). The ICP-MS (VG Elemental PQ3 nuclide) has been modified for use in a glovebox to limit the personnel exposure to the radioactive samples. Isotopes of iodine (I-127 and I-129), technetium (Tc-99), and cesium (Cs-133 and Cs-135) are detected by ICP-MS for the filter solutions. For iodine, quantitative isotopic data on I-127 and I-129 are combined for a total iodine value. Total technetium is assumed from the isotopic Tc-99 data. A total cesium value is calculated from isotopic data on Cs-133 and Cs-135 based on known ratios in the BR-3 spent fuel. 


\section{Selective Trapping of Volatile Fission Products}

\section{RESULTS AND DISCUSSION}

Shown in Table 2 and Fig. 3 are the quantities of iodine per filter and the total per zone for the three tests. Filters are numbered consecutively from the bottom for the filter media in Zone 1 as well as for those in Zones 2 and 3. Comparing iodine values per test, significantly less iodine was collected in Test 1 than for Tests 2 and 3. The most likely explanation for this is incomplete oxidation for Test 1 which did not allow the release of volatile iodine species. Recall that for Test 1 , incomplete oxidation was noted by the lack of fuel separation from cladding. For Test 2, $84 \%$ of the iodine expected from ORIGEN (18) calculations was collected in the AgX filters. A technique does not currently exist for the analytical quantification of iodine in spent BR-3 fuel, hence the use of ORIGEN calculations. For Test 3, complete mass balance of the iodine was achieved. When considering the theoretical capacity of iodine given in Table 1 , only about $6 \%$ of the capacity was utilized in the first filter from Tests 2 and 3. Although low, this is not surprising given the complexity of off-gas collection under actual fuel processing conditions.

Table 3 and Fig. 4 depict the quantities of trapped technetium per filter and zone for the three tests. Filters 4 through 9 for Test 1 were not analyzed due to the lack of discoloration following testing. From tests performed at the KAERI, discoloration has been recognized as an indicator for trapping. Similar to iodine, the effect of incomplete oxidation can be seen for Test 1 on the amount of technetium collected. For Test 2, no technetium was detected on the first two filters and the maximum was on Filter 5. A possible explanation for this is given following the cesium results. The mass balance of technetium for Tests 2 and 3 based on sampling of the fuel prior to testing is $15 \%$ and $72 \%$, respectively. Looking at the loading of Filter 1 for Test 3 compared to the theoretical amount in Table 1 , either $1 \%$ or $5 \%$ of the theoretical value is calculated depending on whether equation (1) or (2) is assumed to be applicable.

Table 2. Iodine collected on $\mathrm{AgX}$ filters (Zone 1) for Tests 1, 2, and 3

\begin{tabular}{lrrr}
\hline $\begin{array}{l}\text { AgX } \\
\text { filter }\end{array}$ & $\begin{array}{c}\text { Test } 1 \\
\text { (ug) }\end{array}$ & $\begin{array}{c}\text { Test 2 } \\
\text { (ug) }\end{array}$ & $\begin{array}{c}\text { Test 3 } \\
\text { (ug) }\end{array}$ \\
\hline 1 & 2453 & 15157 & 17483 \\
2 & 0 & 668 & 1236 \\
3 & 0 & 19 & 59 \\
4 & 0 & 5 & 22 \\
5 & 0 & 16 & 0 \\
Total & 2453 & 15865 & 18800 \\
\hline
\end{tabular}




\section{B. R. Westphal et al.}

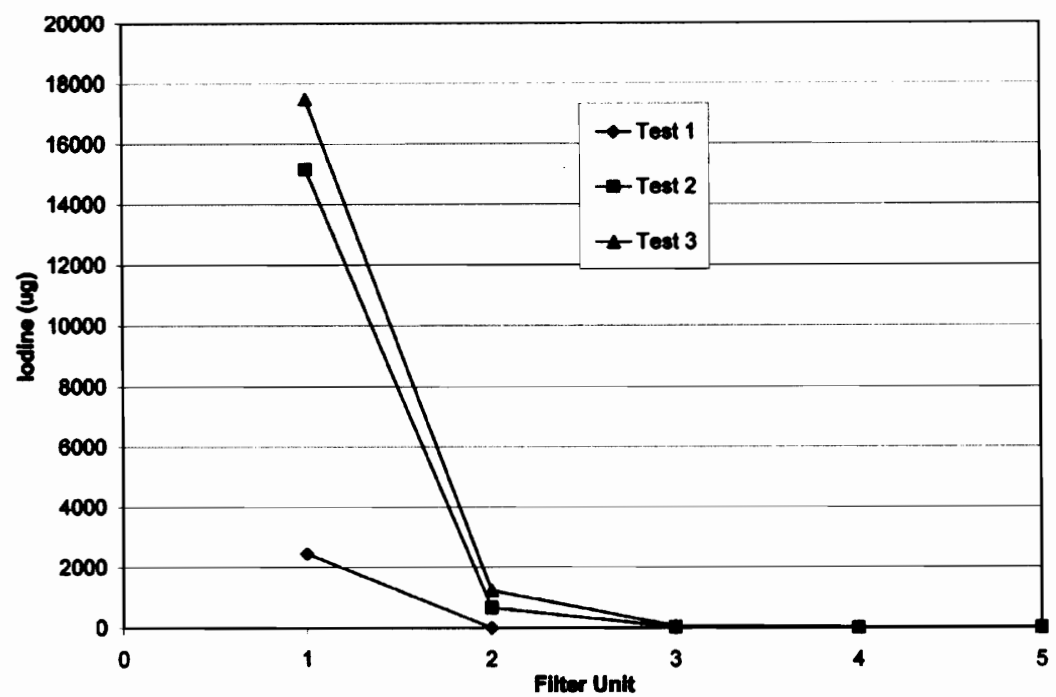

Figure 3. Iodine collected on $\mathrm{AgX}$ filters (Zone 1) for tests with irradiated fuels.

Data for the amount of cesium collected per filter and zone for the three tests are given in Table 4 and Fig. 5. Compared to Test 3, minor amounts of cesium were collected during Tests 1 and 2. The lack of oxidation and the use of an $\mathrm{Al}_{2} \mathrm{O}_{3}-\mathrm{SiO}_{2}$ crucible are the probable causes for

Table 3. Technetium collected on $\mathrm{CaO} /$ fly-ash filters (Zone 2 ) for Tests 1,2 , and 3

\begin{tabular}{lccr}
\hline $\begin{array}{l}\text { CaO/Fly-ash } \\
\text { filter }\end{array}$ & $\begin{array}{c}\text { Test 1 } \\
\text { (ug) }\end{array}$ & $\begin{array}{c}\text { Test 2 } \\
\text { (ug) }\end{array}$ & $\begin{array}{c}\text { Test 3 } \\
\text { (ug) }\end{array}$ \\
\hline 1 & 751 & 0 & 24600 \\
2 & 30 & 0 & 6860 \\
3 & 4 & 169 & 1660 \\
4 & NA & 1950 & 3010 \\
5 & NA & 2510 & 3870 \\
6 & NA & 1370 & 1820 \\
7 & NA & 1150 & 2540 \\
8 & NA & 1130 & 1340 \\
9 & NA & 1150 & 1180 \\
Total & 785 & 9429 & 46880 \\
\hline
\end{tabular}

NA $=$ Not Analyzed 
Selective Trapping of Volatile Fission Products

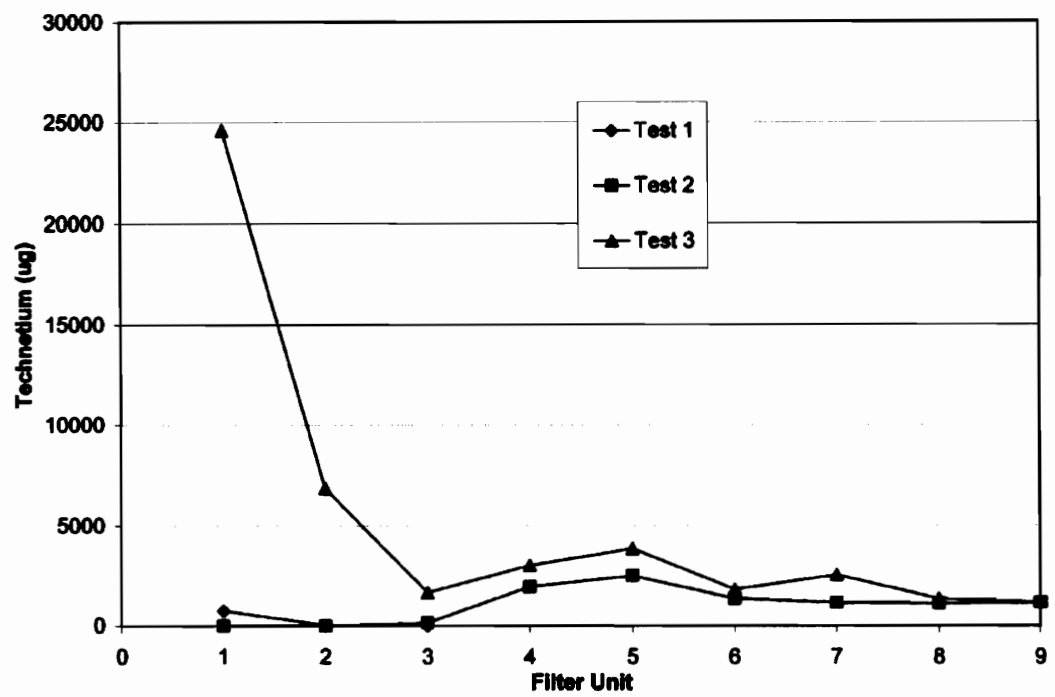

Figure 4. Technetium collected on $\mathrm{CaO} /$ fly-ash filters (Zone 2 ) for tests with irradiated fuels.

cesium not being released to the filters during Tests 1 and 2 . Recall that an Inconel ${ }^{\mathrm{B}}$ crucible was used only for Test 3 . Approximately $66 \%$ of the cesium expected from pre-test sampling was collected in Zone 3 for Test 3. For Filter 1 of Test 3, the percent of the theoretical capacity shown in Table 1 is $6 \%$.

Following Test 2, cesium was detected in the filters of Zone 2 and in the tubing between Zones 1 and 2 (19). Chemical analyses of the filters and tubing revealed both cesium and technetium at a molar ratio of approximately 1:1. A volatile cesium pertechnetate has been proposed

Table 4. Cesium collected on fly-ash filters (Zone 3) for Tests 1, 2, and 3

\begin{tabular}{lccc}
\hline $\begin{array}{l}\text { Fly-ash } \\
\text { filter }\end{array}$ & $\begin{array}{c}\text { Test 1 } \\
\text { (ug) }\end{array}$ & $\begin{array}{c}\text { Test 2 } \\
\text { (ug) }\end{array}$ & $\begin{array}{c}\text { Test 3 } \\
\text { (ug) }\end{array}$ \\
\hline 1 & 1803 & 1687 & 56713 \\
2 & 423 & 1340 & 16500 \\
3 & 203 & 1217 & 28643 \\
4 & 67 & 277 & 18743 \\
5 & 13 & 927 & 13257 \\
Total & 2510 & 5447 & 133857 \\
\hline
\end{tabular}




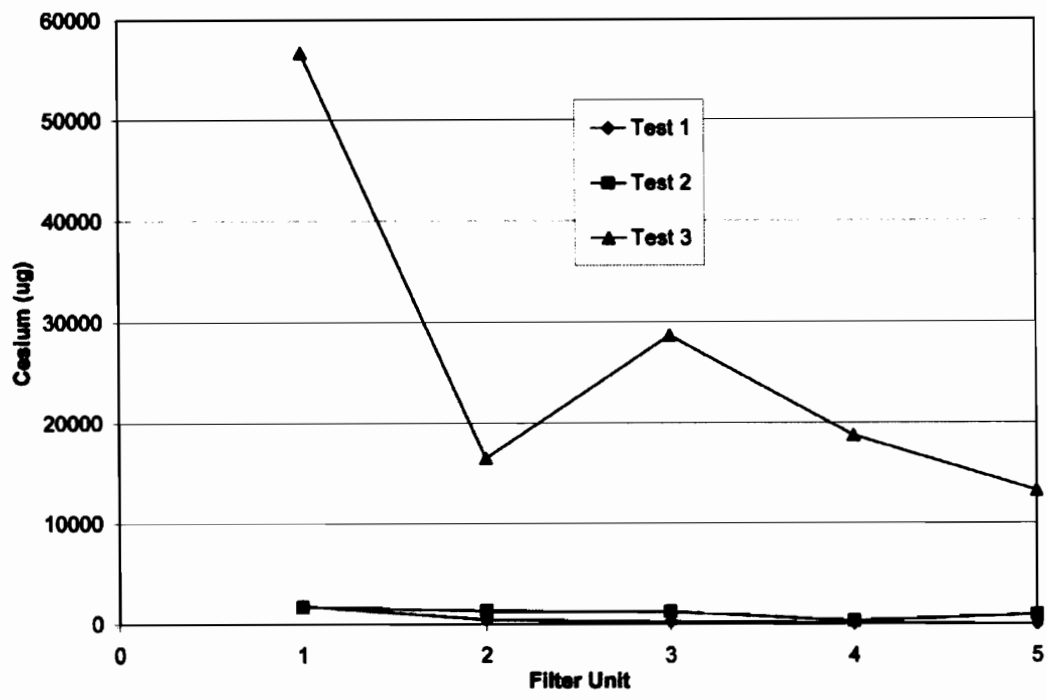

Figure 5. Cesium collected on fly-ash filters (Zone 3) for tests with irradiated fuels.

by several investigators $(20,21)$ according to the following reaction:

$$
\mathrm{Cs}_{2} \mathrm{O}(\mathrm{g})+\mathrm{Tc}_{2} \mathrm{O}_{7}(\mathrm{~g})=2 \mathrm{CsTcO}_{4}(\mathrm{~g})
$$

Given the melting point of $\mathrm{CsTcO}_{4}\left(590^{\circ} \mathrm{C}\right)$ and the temperature (between $150^{\circ} \mathrm{C}$ and $600^{\circ} \mathrm{C}$ ) in the tubing, it appears that cesium pertechnetate condensed in the tubing.

In order to control or prevent the formation of cesium pertechnetate, its origin must be determined. Several possible sources exist:

1. in Zone 2 prior to the reaction of calcia with technetium oxide per equation (3),

2. in Zone 2 per the following reaction:

$$
\mathrm{Cs}_{2} \mathrm{O}(\mathrm{g})+\mathrm{Ca}\left(\mathrm{TcO}_{4}\right)_{2}(\mathrm{~s})=2 \mathrm{CsTcO}_{4}(\mathrm{~g})+\mathrm{CaO}(\mathrm{s})
$$

or

3. during the oxidation cycle in Zone 4 per equation (3). It should be pointed out that even though the reactions in equations (3) and (4) assume that $\mathrm{Cs}_{2} \mathrm{O}$ is the volatile cesium species, other volatile species (e.g. Cs, CsI, $\mathrm{Cs}_{2} \mathrm{O}_{2}$, and $\mathrm{Cs}_{2} \mathrm{Te}$ ) exist (7) and could be substituted into the equations.

Before discussing the possible sources of cesium pertechnetate, the applicable results from Test 3 are given. Negligible amounts of cesium 


\section{Selective Trapping of Volatile Fission Products}

and technetium were found in the tubing between Zones 1 and 2. A comparable quantity $(\sim 10 \mathrm{mg})$ of cesium was detected in Zone 2 for Test 3 as for Test 2. Technetium was present on the first two filters of Zone 2, unlike for Test 2. The operating temperature of Zone 3 was raised to $1000^{\circ} \mathrm{C}$ from $800^{\circ} \mathrm{C}$. Despite the increased quantities of volatile cesium entering the filter system for Test 3 , the increased temperature for Zone 3 appeared to prevent the condensation of cesium pertechnetate.

For the first possible source, the likelihood that both volatile cesium and technetium species are present at the same time in Zone 2 is not probable based on previous testing (7). Removal of technetium oxide is easier due to its higher vapor pressure and thus, would be volatized early in the processing sequence.

For Test 2, the reaction according to equation (4) probably occurred based on the stripping of technetium from the first two filters of Zone 2. This reaction would be favored to the right given the relative stability of $\mathrm{CaO}$ with respect to the cesium species. Unfortunately, no thermodynamic data exist for calcium and cesium pertechnetates to determine the exact direction of the equation. For Test 3, there was no evidence of cesium pertechnetate or stripping of technetium so the source of $\mathrm{CsTcO}_{4}$ could not be from Zone 2. Obviously, the increased temperature of Zone 3 in Test 3 was a factor in the stability of cesium pertechnetate.

For Zone 4 to be the source of cesium pertechnetate, cesium pertechnetate must only be reactive with fly-ash at certain temperatures. Hence, it either passes through or is retained by Zone 3 for Tests 2 and 3, respectively. Due to the lack of thermodynamic data on cesium pertechnetate, potassium pertechnetate was evaluated against fly-ash per the following reaction:

$$
2 \mathrm{KtcO}_{4}+\mathrm{Al}_{2} \mathrm{O}_{3}+4 \mathrm{SiO}_{2}=2 \mathrm{KalSi}_{2} \mathrm{O}_{6}+\mathrm{Tc}_{2} \mathrm{O}_{7}
$$

A threshold temperature of approximately $990^{\circ} \mathrm{C}$ exists for this reaction; at temperatures less than $990^{\circ} \mathrm{C}$, the reaction goes to the left and at temperatures greater than $990^{\circ} \mathrm{C}$ the reaction goes to the right (22). Thus of the three possibilities, it seems the most likely that cesium pertechnetate is being formed in Zone 4 and either passing through or reacting with flyash in Zone 3 depending on the temperature of Zone 3.

The only item left unexplained then is the minor amount of cesium detected in Zone 2 following Test 3 . This may be justified by the equilibrium nature of the reaction between cesium pertechnetate and fly-ash, that is, products may dominate but reactants are still present.

Since Test 3 was unaffected by oxidation or crucible material, the total mass balance of cesium and technetium will be discussed. For cesium, $66 \%$ was collected in Zone 3, 5\% in Zone 2, and $0 \%$ in the tubing for a total of 
$71 \%$. The $71 \%$ collected matches closely with the $70 \%$ removed from fuel samples following oxidation. For technetium, the $72 \%$ collected in Zone 2 was the entire amount since no significant quantities were found in the tubing or in Zone 3. From fuel samples, $95 \%$ of the technetium was removed thus creating a difference of $23 \%$ or about $15 \mathrm{mg}$. Several possibilities exist for the discrepancy including non-representative sampling of the fuel following testing, loss of material during filter disassembly/ sampling operations, incomplete dissolution of the filter media in the analytical laboratory, and technetium distributed to an area not sampled.

\section{CONCLUSIONS}

An off-gas treatment system has been designed and tested with irradiated spent oxide fuels for the recovery of volatile iodine, technetium, and cesium. The ultimate performance of the filter media during testing has been quite successful with respect to the collection of these volatiles. For iodine, complete removal and collection was achieved with the $\mathrm{AgX}$ filter media. The mass balance on cesium removed and collected was very good despite a minor amount being found on the $\mathrm{CaO} /$ flyash filters. The characteristics of cesium trapping have been shown to be dependent on variables such as cesium species, temperature, pressure, and atmosphere. Thus, research will continue on the containment of cesium within the fly-ash filter media. Technetium removal and collection was promising in that mass balance was nearly achieved by the $\mathrm{CaO} /$ flyash filters and potential areas for misbalance were given.

In addition to the off-gas characteristics, several other areas have been developed. Following the equipment challenges during Tests 1 and 2, specifically the ability to oxidize the fuel and avoid crucible interactions, more efficient designs and material choices were realized. The measured capacities of the filter media have been compared to the theoretical maximums. In all cases, the measured capacities are significantly less than the theoretical capacities due to inefficiencies encountered under non-ideal conditions. The most likely source of cesium pertechnetate was determined and discussed in terms of results from testing and potential vapor chemistry within the off-gas treatment system. Based on the source determination, testing will continue with irradiated fuels for the minimization or control of cesium pertechnetate.

\section{ACKNOWLEDGMENTS}

The authors would like to acknowledge the HFEF operations and Analytical Laboratory personnel for their contributions to the testing 


\section{Selective Trapping of Volatile Fission Products}

program. In addition, the filter media was developed and provided by KAERI. Work supported by the U.S. Department of Energy, Office of Nuclear Energy, Science, and Technology, under DOE-NE Idaho Operations Office Contract DE-AC07-05ID14517.

\section{REFERENCES}

1. Song, K.C.; Park, G.I.; Lee, J.W.; Park, J.J.; Yang, M.S. Fractional release behavior of volatile and semi-volatile fission products during a voloxidation and OREOX treatment of spent PWR fuel. Nucl. Tech., in publication.

2. Westphal, B.R.; Bateman, K.J.; Lind, R.P.; Wahlquist, D.L. (2006) Recent progress in the DEOX process. Trans. American Nucl. Soc., 94: 103.

3. Herrmann, S.D.; Li, S.X.; Sell, D.A.; Westphal, B.R. (2007) Electrolytic reduction of spent nuclear oxide fuel - effects of fuel form and cathode containment materials on bench-scale operations. Proc. Global 2007. 758.

4. Li, S.X.; Vaden, D.; Benedict, R.W.; Johnson, T.A.; Westphal, B.R.; Fredrickson, G.L. (2007) Integrated efficiency test for pyrochemical fuel cycles. Proc. Global 2007. 766.

5. Brand, G.E.; Murbach, E.W. (1965) Pyrochemical reprocessing of $\mathrm{UO}_{2}$ by AIROX: Summary report. NAA-SR-11389.

6. Bodine, J.E.; Groce, I.J.; Guon, J.; Hanson, L.A. (1964) Oxidative decladding of uranium oxide Fuels. Nucl. Sci. Eng., 19: 1.

7. Westphal, B.R.; Bateman, K.J.; Lind, R.P.; Howden, K.L.; Del Cul, G.D. (2005) Fission product removal from spent oxide fuel by head-end processing. Proc. Global 2005.

8. Piet, S.; Bjornard, T.; Dixon, B.; Gombert, D.; Laws, C.; Matthern, G. (2007) Which elements should be recycled for a comprehensive fuel cycle. Proc. Global 2007. 1595.

9. Choi, B.S.; Park, G.I.; Kim, J.H.; Lee, J.W.; Ryu, S.K. (2001) Adsorption equilibrium and dynamics of methyl iodide in a silver ion-exchanged zeolite column at high temperatures. Adsorption., 7: 91.

10. Maeck, W.J.; Pence, D.T.; Keller, J.H. (1968) A highly efficient inorganic adsorber for airborne iodine species. Proc. 10th AEC Air Clean 185.

11. Shin, J.M.; Park, J.J. (2001) Trapping characteristics of cesium in off-gas stream using fly-ash filter. Korean J. Chem. Eng., 18: 1010.

12. Shin, J.M.; Kim, K.Y.; Park, J.J.; Shin, S.W. (2005) Trapping characteristics for various cesium compounds by fly-ash. J. Kor. Solid Wastes Eng. Soc., 22: 27.

13. Mukerji, J.; Kayal, P.B. (1975) Reaction of $\mathrm{CsNO}_{3}$ and $\mathrm{RbNO}_{3}$ with natural aluminosilicates. Mat. Res. Bull., 10: 1067.

14. Strachan, D.M.; Schulz, W.W. (1979) Characterization of Pollucite as a Material for Long-Term Storage of Cesium-137. Am. Cer. Soc. Bull., 58: 865 .

15. Maas, E.T.; Longo, J.M. (1980) Confinement of ruthenium oxides volatized during nuclear fuel reprocessing. Nucl. Tech., 47: 451. 
B. R. Westphal et al.

16. Park, J.J.; Chun, K.S.; Shin, J.M.; Kim, J.H.; Park, H.S. (1997) Thermal stability of cesium trapped on a fly ash. Proc. Global 1997. 1208.

17. Shin, J.M.; Park, J.J.; Song, K.C. (2007) Cesium trapping characteristics on fly ash filter according to different carrier gases. Proc. Global 2007. 610.

18. Croff, A.G. (1983) ORIGEN2: A versatile computer code for calculating the nuclide compositions and characteristics of nuclear materials. Nucl. Tech., 62 (3): 335.

19. Westphal, B.R.; Lind, R.P.; Giglio, J.J.; Cummings, D.G.; Huntley, M.W.; Morgan, C.D.; Bateman, K.J.; Wahlquist, D.L.; Sell, D.A. (2007) Direct assay of filter media following DEOX testing. Proc. Global 2007. 605.

20. Migge, H. (1989) Simultaneous evaporation of Cs and Tc during vitrification - A thermochemical approach. Scientific Basis for Nuclear Waste Management XIII., 176: 411.

21. Rard, J.A.; Rand, M.H.; Anderegg, G.; Wanner, H. (1999) Chemical Thermodynamics of Technetium; Elsevier Press: New York, NY.

22. Roine, A. (2002) Outokumpu HSC chemistry 5.0. 